\title{
Vigour evaluation of cocksfoot (Dactylis glomerata L.) seeds of different age
}

\author{
RYSZARD J. GÓRECKI, DOROTA MIERZEJEWSKA, JAN KASZUBA*, \\ STANISLAW GRZESIUK and ANDRZEJ REJOWSKI
}

Department of Plant Physiology and Biochemistry, University of Agriculture and Technology, Kortowo 40, 10-957 Olsztyn, Poland

(Received: June 14, 1989)

Abstract

Cocksfoot seeds cv. Baza and Bepro, harvested in 1986, 1985, 1984, and 1983 and stored in a store-house were studied. Seed lots did not differ greatly in their viability. However, significant reduction in seed vigour due to natural ageing as measured by soil emergence, seedling growth rate, and ethanol and osmotic stress tests was noted. A conductivity test did not indicate vigour changes of ageing seeds, and its correlation with field emergence was poor. The methodical aspects of vigour evaluation of cocksfoot seeds are discussed.

\section{INTRODUCTION}

Stored seeds undergo ageing at a rate depending on the genetic properties of seeds, preharvest effects, seed maturity, and the influence of external factors, mainly moisture, temperature, and oxygen pressure (Grzesiuk and Kulka, 1981; Justice and B a s s, 1978; R oberts, 1981). Ageing in seeds involves their deterioration due to structural, compositional, and functional changes within the tissues (Abdul-Baki, 1980; Bewley and Black, 1982; Górecki et al., 1985; Powell and Mat thews, 1977; Roberts and Ellis, 1982; R oss, 1980). Vigour is the best indicator of the degree of seed deterioration because it decreases earlier and faster than viability (Copeland, 1976; Gó recki, 1986).

Much work in the past has been done on the vigour examination of both naturally and artificially aged seeds of cereals and legumes (Ching, 1982; Górecki, 1982; Górecki and Harman, 1987; Grzesiuk and Tłuczkiewicz, 1982). In this work we evaluated the vigour of naturally aged cocksfoot seeds. Different methods of vigour evaluation are also discussed.

* Present address: Plant Breeding Station, Bartążek, 11-033 Bartąg, Poland. 


\section{MATERIALS AND METHODS}

Cocksfoot (Dactylis glomerata L.) cv. Baza and Bepro seeds harvested in 1983, 1984, 1985, and 1986 at the Plant Breeding Station near Olsztyn were studied. After harvest seeds were dried at room temperature and stored in linen bags in a store-house under ambient conditions. Before starting experiments, seed lots were transferred into the laboratory and stored at $2-3^{\circ} \mathrm{C}$ and $60 \%$ relative humidity. Such conditions protected seeds from appreciable deterioration during the course of this study. All experiments were performed in the spring of 1987, when seed dormancy was over. One seed lot (collected from 2-3 sublots) represented each year and cultivar.

\section{LABORATORY GERMINATION AND SOIL EMERGENCE}

Germination was assayed by placing 100 seeds on filter paper (Whatman No. 3) in a Petri dish moistened with $4 \mathrm{ml}$ deionized water at $20^{\circ} \mathrm{C}$. After 7 and 21 days, germination rate and germination capacity were recorded, respectively (International Seed Testing Association, 1976).

The soil emergence test was performed in the greenhouse (on 4 May) and in the field (on 25 May). Each time 100 seeds were sown by hand $5 \mathrm{~mm}$ deep in rows $1 \mathrm{~m}$ long in a medium loam soil. There were eight replicates and emergence was counted twice during a period of four weeks.

\section{VIGOUR DETERMINATION}

Seedling growth rate analysis. 50 seeds were placed between moistened rolled blotters at $20^{\circ} \mathrm{C}$. After 5 and 10 days the length of the coleoptile and radicle and the fresh weight of seedlings were determined.

Conductivity of leachates. For the analysis of leachates, $1 \mathrm{~g}$ of seeds was rinsed with deionized water, then soaked in $100 \mathrm{ml}$ deionized water at $20^{\circ} \mathrm{C}$ for 24 hours. The electrical conductivity of the water was measured using a Radelkis OK-102/1 conductivity meter. The reading was expressed in $\mu \mathrm{S}$ per $\mathrm{g}$ seed air dry mass.

Osmotic stress. One hundred seeds of each lot were germinated on filter

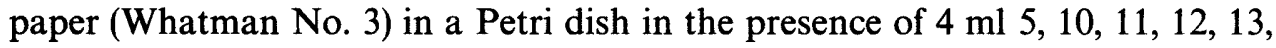
$14,17.5$ or $20 \%(\mathrm{w} / \mathrm{v})$ polyethylene glycol (PEG) 6000 (Carbowax) water solution. Seed samples germinated in the presence of water were controls. Osmotic equivalents of PEG solutions were calculated according to $\mathrm{Michel}$ and Kaufmann (1973) and were: $-57 \mathrm{KPa},-163 \mathrm{KPa},-190 \mathrm{KPa}$, $-219 \mathrm{KPa},-250 \mathrm{KPa},-283 \mathrm{KPa},-318 \mathrm{KPa},-524 \mathrm{KPa}$, respectively. After 7 days of germination at $20^{\circ} \mathrm{C}$ (germination rate), counts were made of viable seeds. 
Ethanol stress. Samples of 100 seeds were placed in a $125 \mathrm{ml}$ Erlenmeyer flasks containing about $20 \mathrm{ml}$ of $5,10,15$ and $20 \%$ (v/v) ethanol. Flasks were stoppered with rubber stoppers and left for $0,2,4,6$, or 24 hours at $20^{\circ} \mathrm{C}$; then the alcohol was poured off, and the seeds were washed with deionized water and tested for germination as above. Non-treated seeds were used as controls.

All germination and vigour tests were conducted at least four times in two series.

\section{RESULTS}

1. GERMINATION AND SEEDLING EMERGENCE

Cocksfoot seeds lost their viability rather quickly as measured in terms of speed of germination (Fig. 1). Germination capacity showed smaller differences in seed quality and ranged between $93 \%$ (1-year-old seeds) and $75 \%$ (4-year-old seeds). Both indicators pointed, however, to more rapid ageing of seeds of cv. Baza than Bepro.

Soil emergences also depended on the seed age; three- and four-year-old seeds always emerged weaker than one- and two-year-old ones (Fig. 2). Field emergences were 20 to $40 \%$ lower than germination. The correlation coefficients for both cultivars between laboratory germination and field emergence were highly significant (Table 2). However, the fact is that field emergence corresponded the best to greenhouse emergence $(r=0.79,0.81)$.
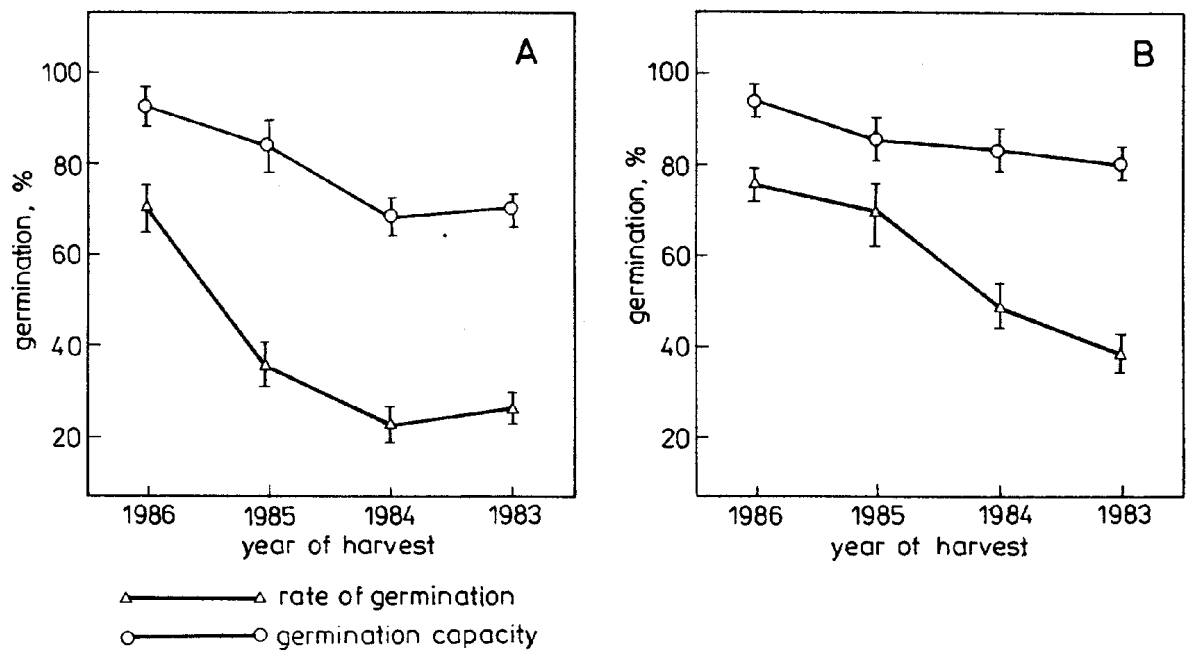

Fig. 1. Germination of cocksfoot seeds cv. Baza (A) and Bepro (B) of different ages 


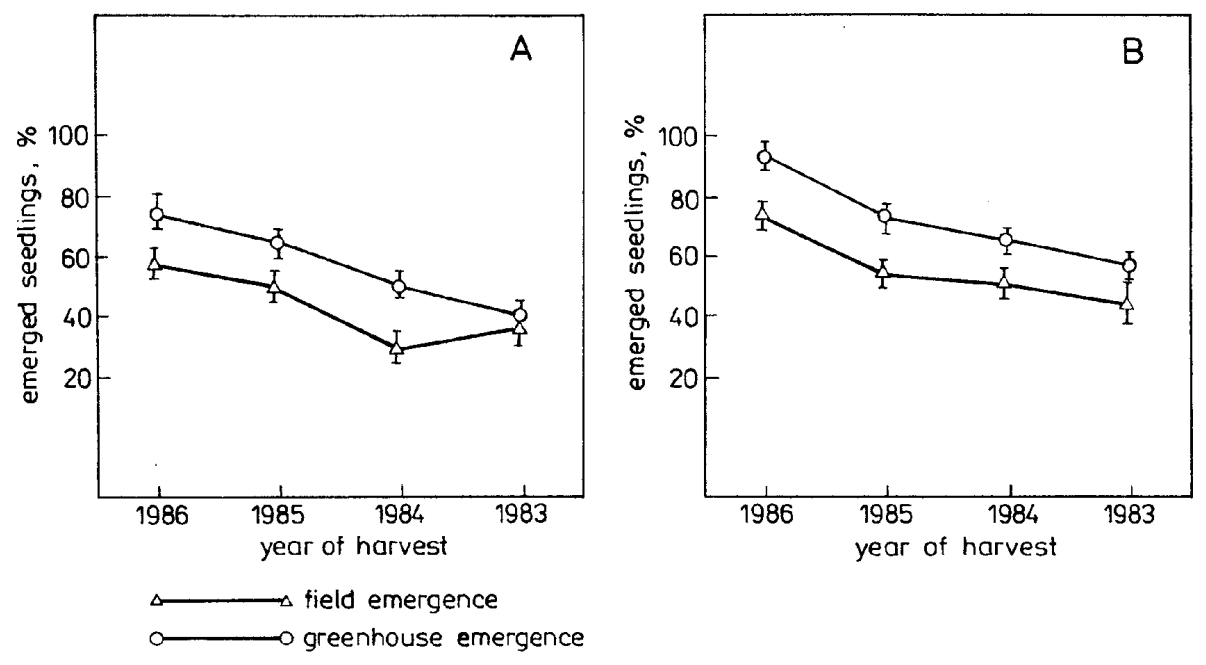

Fig. 2. Field and greenhouse emergence of cocksfoot seeds cv. Baza (A) and Bepro (B) of different ages

2. VIGOUR

A gradual decrease of seed vigour during their ageing was observed when a method of seedling growth rate was used (Table 1). The oldest seeds produced the weakest seedlings, whereas the best seedlings were produced by the youngest ones. Generally, radicle length and seedling fresh weight showed vigour reduction more than coleoptile length. The differences between years were most pronounced when measurements were made after 5 days of germination. It can be noticed that cocksfoot seeds of both cultivars lose their vigour much earlier and faster than viability. For example the germination capacity of seeds of cv. Bepro decreased after 4-year-ageing about $10 \%$, but seedling fresh weight (determined after 5 days) was lowered over 60\% (Fig. 1B, Table 1).

Cocksfoot seeds showed differentiated reactions to osmotic stress (Fig. 3). Moderate water stress (up to - $160 \mathrm{KPa}$ ) did not cause significant changes in seed germination. High concentrations of PEG ( -300 and more $\mathrm{KPa}$ ) strongly limited seed germination. Seeds of cv. Baza were more sensitive to osmotic stress than those of cv. Bepro. For example, the stress required to lower the germination of seeds from 1986 was $-205 \mathrm{KPa}$ for Baza and $-310 \mathrm{KPa}$ for Bepro. Four-year-old seeds, i.e. with low vigour level, were more sensitive to the osmotic stress than one-year-old seeds with high vigour level.

Germination of seeds subjected to ethanol stress depended on alcohol concentration, time of stress duration, and seed age (Figs. 4 and 5). The highest deterioration was caused by 24 hours soaking in 15 and $20 \%$ ethanol. Seed 
Table 1

Seedling growth rate of cocksfoot seeds, cv. Baza and Bepro of different ages

\begin{tabular}{|c|c|c|c|c|c|c|}
\hline \multirow{2}{*}{$\begin{array}{l}\text { Year of } \\
\text { harvest }\end{array}$} & \multicolumn{2}{|c|}{$\begin{array}{l}\text { Mean coleoptile length } \\
\text { mm }\end{array}$} & \multicolumn{2}{|c|}{$\begin{array}{l}\text { Mean radicle length } \\
\mathrm{mm}\end{array}$} & \multicolumn{2}{|c|}{$\begin{array}{l}\text { Whole seedling fresh weight } \\
\text { mg }\end{array}$} \\
\hline & $\begin{array}{l}\text { after } 5 \\
\text { days }\end{array}$ & $\begin{array}{l}\text { after } 10 \\
\text { days }\end{array}$ & $\begin{array}{l}\text { after } 5 \\
\text { days }\end{array}$ & $\begin{array}{l}\text { after } 10 \\
\text { days }\end{array}$ & $\begin{array}{l}\text { after } 5 \\
\text { days }\end{array}$ & $\begin{array}{l}\text { after } 10 \\
\text { days }\end{array}$ \\
\hline \multicolumn{7}{|c|}{ cv. Baza } \\
\hline 1986 & $3.8 \pm 0.9$ & $28.2 \pm 1.5$ & $19.5 \pm 1.3$ & $43.9 \pm 1.6$ & $4.5 \pm 0.4$ & $7.4 \pm 0.2$ \\
\hline 1985 & $2.8 \pm 0.9$ & $27.4 \pm 1.7$ & $15.2 \pm 2.5$ & $43.4 \pm 1.6$ & $4.2 \pm 0.3$ & $7.8 \pm 0.7$ \\
\hline 1984 & $2.7 \pm 1.0$ & $25.3 \pm 2.6$ & $16.2 \pm 1.7$ & $33.9 \pm 1.7$ & $3.1 \pm 0.4$ & $6.3 \pm 0.4$ \\
\hline 1983 & $0.3 \pm 0.3$ & $20.4 \pm 2.4$ & $4.9 \pm 3.5$ & $32.9 \pm 2.5$ & $1.9 \pm 0.7$ & $6.3 \pm 0.2$ \\
\hline \multicolumn{7}{|c|}{ cv. Bepro } \\
\hline 1986 & $8.8 \pm 0.9$ & $39.0 \pm 1.4$ & $29.2 \pm 0.5$ & $53.4 \pm 1.2$ & $5.2 \pm 0.3$ & $8.0 \pm 0.1$ \\
\hline 1985 & $6.4 \pm 7.0$ & $35.7 \pm 2.3$ & $24.6 \pm 1.2$ & $47.3 \pm 0.9$ & $4.5 \pm 0.2$ & $7.0 \pm 0.3$ \\
\hline 1984 & $4.1 \pm 0.7$ & $32.3 \pm 2.1$ & $20.1 \pm 1.4$ & $46.7 \pm 1.8$ & $3.9 \pm 0.2$ & $7.2 \pm 0.2$ \\
\hline 1983 & $1.7 \pm 0.2$ & $33.2 \pm 1.7$ & $15.7 \pm 0.7$ & $46.1 \pm 1.2$ & $3.7 \pm 0.2$ & $7.1 \pm 0.2$ \\
\hline
\end{tabular}
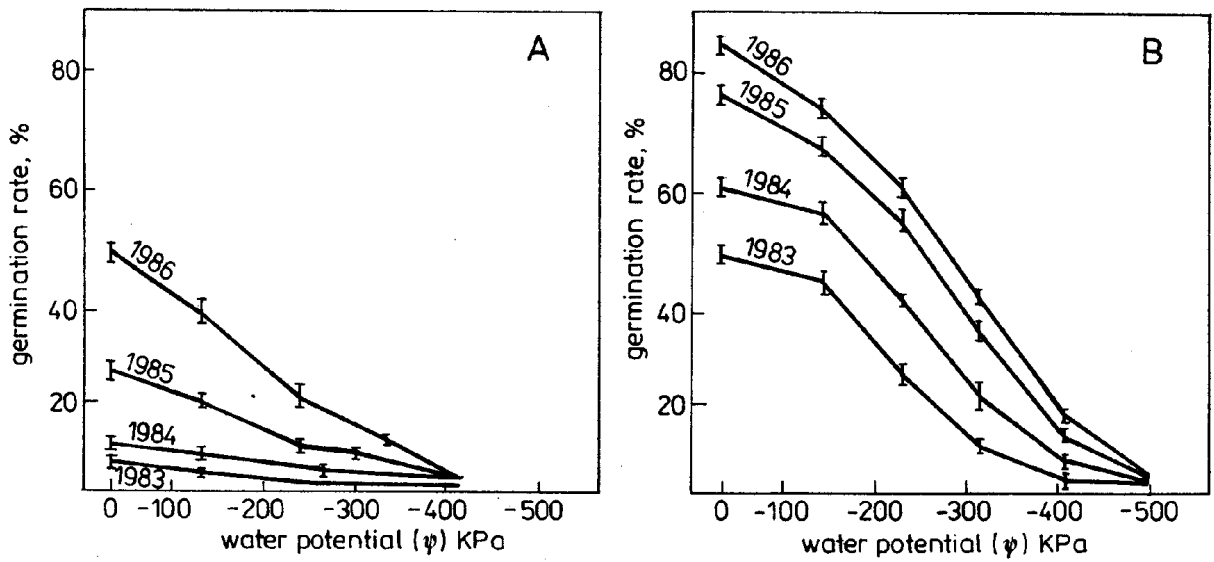

Fig. 3. Germination rate of cocksfoot seeds cv. Baza (A) and Bepro (B) of different ages in the solutions of PEG 600 with different water potentials.

treatment by 5 and $10 \%$ ethanol for 2 hours did not affect seed quality significantly. Surprising data were received while treating seeds of both cultivars with high (40-96\%) alcohol concentrations, even during 24 hours (data not presented here). Such treatment resulted in small reduction of germination. Considering the resistance of seeds of different ages to alcohol stress the following dependence can be noticed: the older the seed, the more sensitive to stress. 

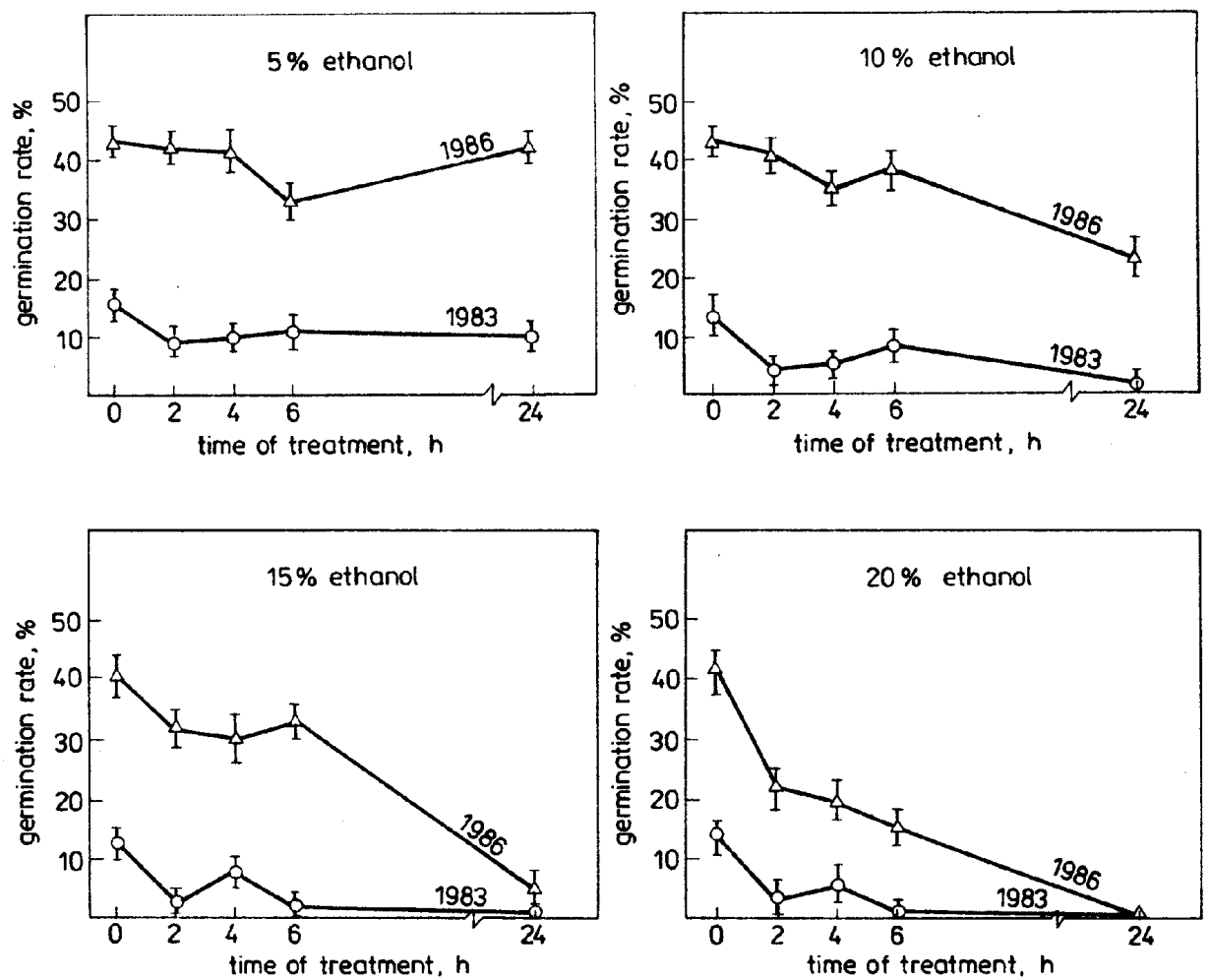

Fig. 4. Germination rate of cocksfoot seeds cv. Baza harvested in 1986 and 1983, treated with different concentrations of ethanol solutions during 2, 4, 6 and 24 hours

Electrical conductivity of steep water was different within the examined samples (Fig. 6). Increased conductivity was seen in cv. Baza from 1983 and 1984 in comparison to the seeds from 1985 and 1986. Such a dependence was not noticed in cv. Bepro, because the conductivity reading for the seeds from 1984 was lower than from 1985 and 1986. These data show some disagreement in vigour estimation of cocksfoot seeds by the conductivity method in comparison to other tests.

\section{DISCUSSION}

Several years seed storage of cocksfoot in a store-house did not affect greatly their viability, but it decreased their vigour significantly. Therefore, vigour examination is very important for a proper estimation of cocksfoot seed quality. Up till now there have not been worked out any single simple and uniform methods for vigour determination of different seed species. It is due to different understandings of vigour term and vigour complexity (Górecki, 

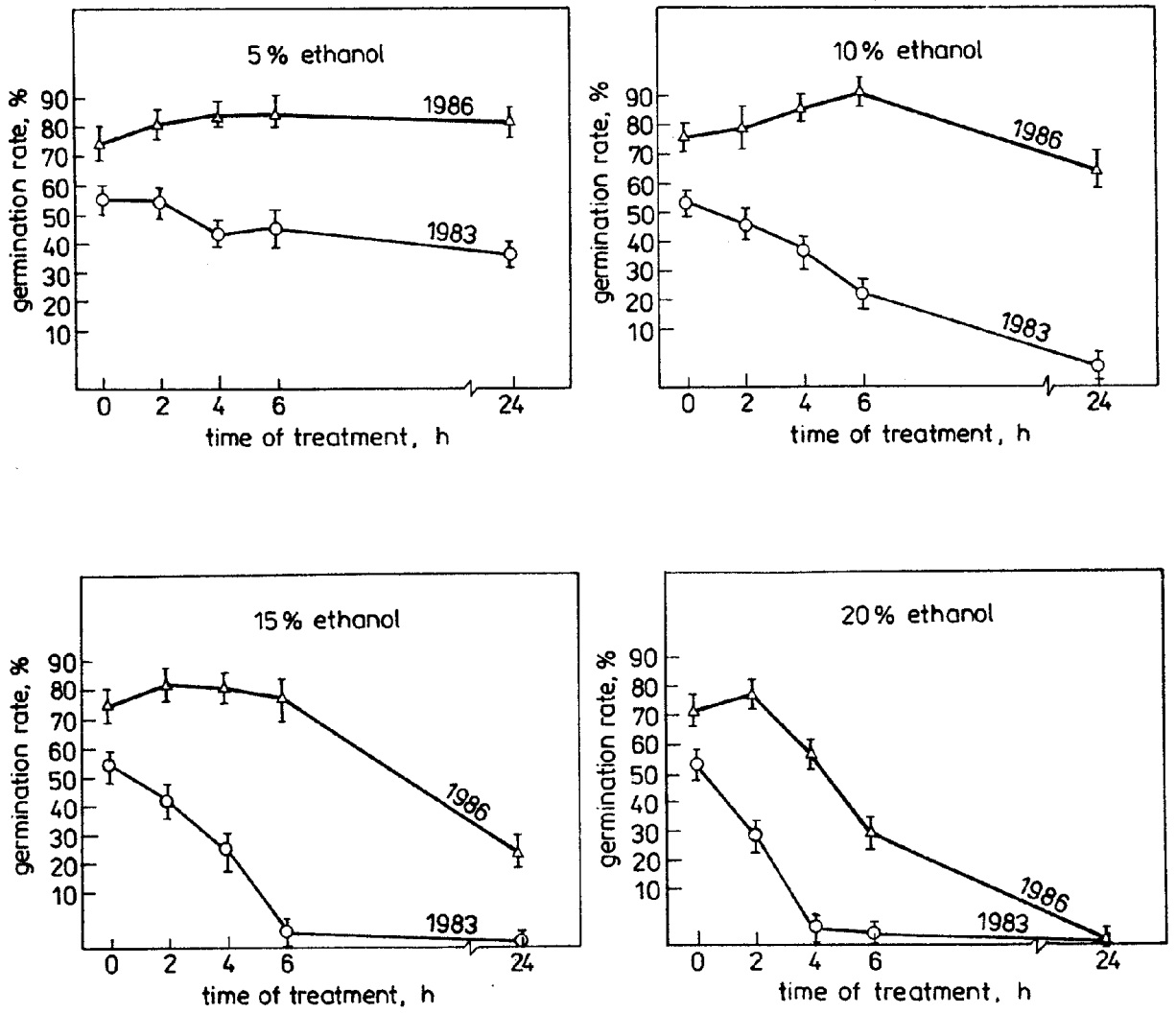

Fig. 5. Germination rate of cocksfoot seeds cv. Bepro harvested in 1986 and 1983, treated with different concentrations of ethanol solution during 2, 4, 6 and 24 hours

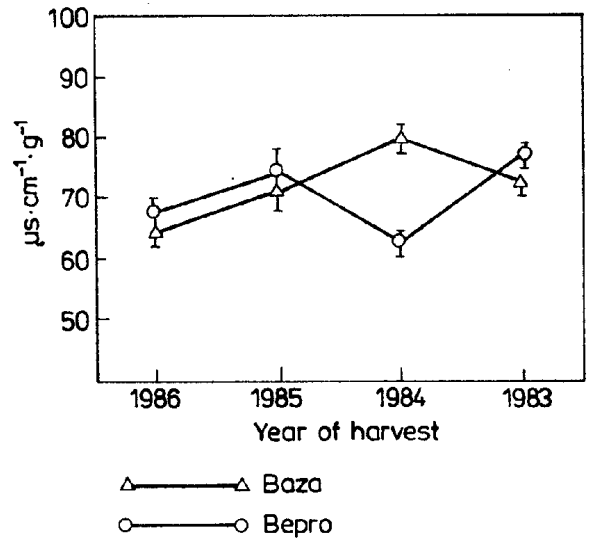

Fig. 6. Conductivity of cocksfoot seeds leachates 
1986; Halmer and Bewley, 1984). Therefore, vigour should be examined by a few methods, adjusted to proper seed material (Grzesiuk and Górecki, 1981). The object of any vigour test must be to indicate or rank the ability of a seed lot to perform under stress, whether this is due to ageing during storage or other factors. The final test must be what happens in the field.

Germination rate (percentage of viable seeds after 7 days) can be a very simple and useful test for cocksfoot seed vigour determination. It showed differences in seed quality and correlated with field emergences relatively well $(r=0.7-0.6)$ as compared to other indicators (Table 2), though no better than germination capacity.

Table 2

Correlations of field emergence with viability and vigour indicators of cocksfoot seeds

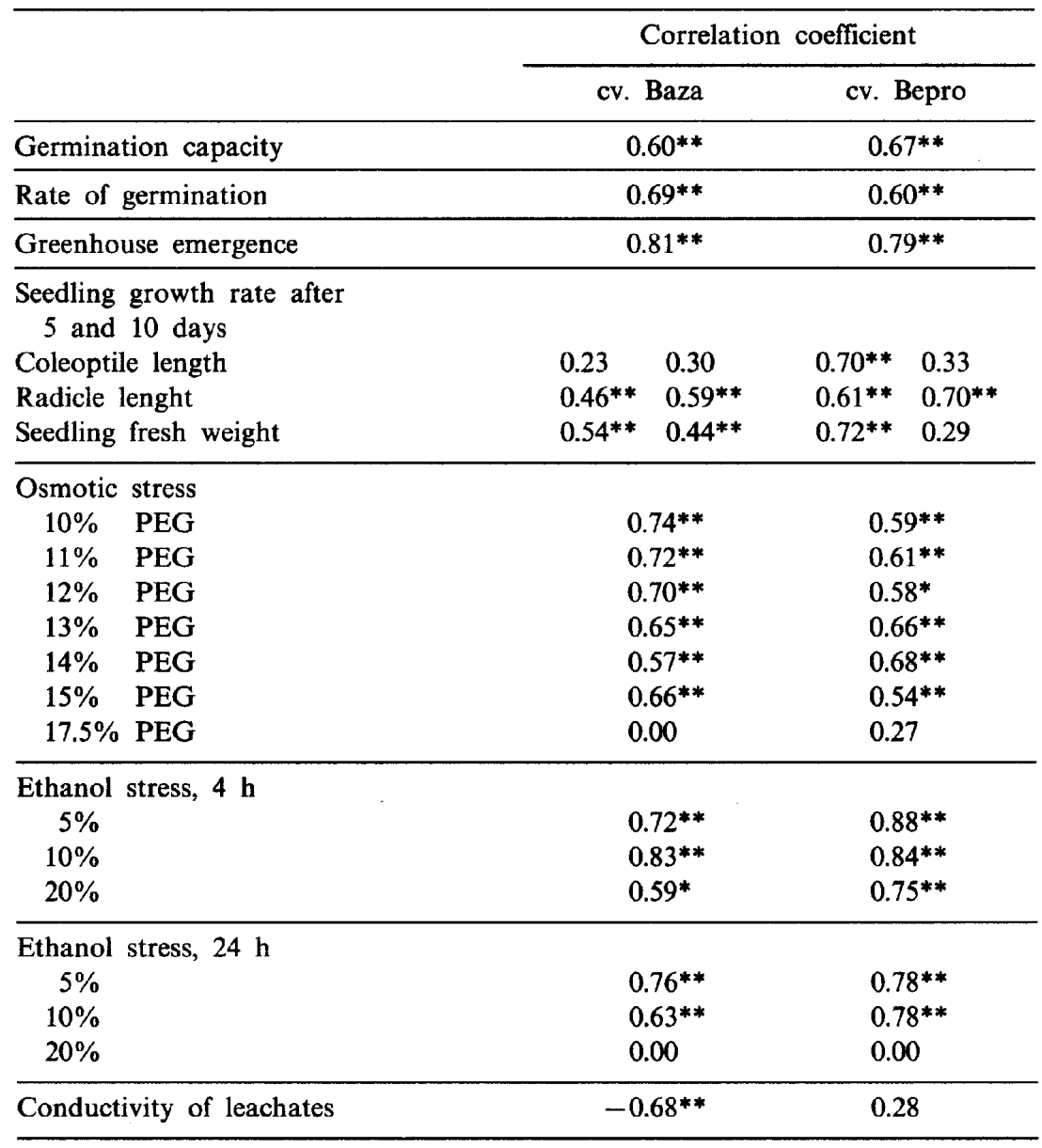

*Significant at $P=0.05 ; *$ Significant at $P=0.01$. 
Seedling growth rate is a commonly used method of seed vigour examination in many species (Górecki, 1986; Grzesiuk and Tłuczkiewicz, 1982; Perry, 1977). In our studies this test appeared to give rather low $r$ values, especially for coleoptile length (Table 2).

In Tables 1 and 2 data are shown for 5 days of germination. Analysis performed after 3 or 4 days did not provide any better information about cocksfoot seed quality (data not shown here). Thus seedling growth rate analysis, however, being a very simple method can be considered as a supplementary test for cocksfoot seed vigour studies.

Grass seeds are often subjected to drought stress which results in poor field emergence. Such drought conditions can be stimulated in the laboratory by germinating seeds in PEG 6000 solution with specific osmotic potential ( $\mathrm{Hadas}$, 1977). The rate of germination of cocksfoot seeds under water stress was markedly reduced. Taking into consideration our experimental data (Fig. 3, Table 2) we have come to the conclusion that PEG solution with osmotic potential ranging from $-160 \mathrm{KPa}$ to $-320 \mathrm{KPa}(10$ to $15 \% \mathrm{PEG})$ may be used in vigour analysis of cocksfoot. However, it should be mentioned that this stress test was no better in predicting field emergence than germination capacity.

Seed treatment by proper concentration of methanol or ethanol causes seed deterioration, and the rate of it is suggested to be an indicator of soybean and sunflower seed quality (Fetch and Schneiter, 1983; Mugnisjah and Nakamura, 1986; Musgrave et al., 1980). Fetch and Schneiter (1983) found that the $20 \%$ methanol stress test during 2 hours gave the best separation into varying degrees of seed vigour in sunflower. The present report indicates a deteriorating effect of ethanol stress on cocksfoot seeds and its usefulness in a vigour examination of these seeds. Data presented in Table 2 show that only the stress test (at concentrations 5 and 10\%, during 4 hours) appears to give better $r$ values than germination. The other vigour tests correlated more poorly with field performance.

Controlled deterioration and AA-test are suggested as routine tests for small-seeded species (AOSA 1983; Perry, 1981). We found that the AA-test (seeds stored at $40^{\circ} \mathrm{C}$ and $100 \%$ relative humidity) was not effective in vigour determination of cocksfoot (unpublished data). In contrast to our findings, Marshall and Naylor (1985) presented a significant correlation between field emergence and a controlled deterioration test in Italian ryegrass.

The conductivity test is used succesfully as an indicator of field emergence of several large-seeded legume species and cereals (Grzesiuk and Tłuczkiewicz, 1982; Powell, 1986; Powell and Matthews, 1981). The best correlation between conductivity and seed vigour was obtained when ageing seeds were studied (Górecki, 1982). Such a good relationship was not observed in cocksfoot seeds. Also Marshall and Naylor (1985) and Ching and Schoolcraft (1968) found poor correlation between conductivity and 
germination or field emergence of Italian ryegrass. This may be due to leaching of electrolytes from the lemma and palea masking the differences between seed lots (Marshall and $\mathrm{Naylor,1985).} \mathrm{Besides,} \mathrm{cocksfoot} \mathrm{seed} \mathrm{density} \mathrm{is} \mathrm{rather}$ small and differentiated within the seed lot; therefore seeds do not submerge uniformly in water, which in turn could make difficult leaching out electrolytes into the water. Additionally, different conditions at seed ripening and harvest between years could account for different accumulations of electrolytes in seeds, masking the effect of storage conditions.

\section{CONCLUSION}

None of the vigour tests beyond the ethanol test was better than germination in the evaluation of ageing cocksfoot seed quality. Application of both the ethanol and osmotic stress test needs further standarization studies. Seedling growth rate analysis, however, showing a marked reduction of seed vigour due to storage, did not predict satisfactory seedling performance in the field. Surprisingly, the conductivity method did not indicate factural vigour changes of ageing seeds and consequently can not be used as a vigour test of cocksfoot seed.

\section{REFERENCES}

Abdul-Baki S. A., 1980. Biochemical aspects of seed vigour. Hortscience, 15: 765-771.

Association of Official Seed Analysts, 1983. Seed vigour testing handbook. Contribution, no. 32.

Bewley J. D., Black M., 1982. Physiology and biochemistry of seeds. II. Viability, dormancy, and environmental control. Springer-Verlag, Berlin, Heidelberg, New York.

Ching T. M., 1982. Adenosine triphosphate and seed vigour. [In:] The physiology and biochemistry of seed development, dormancy, and germination. A. A. Khan (ed.), pp. 487-506.

Ching T. M., Schoolcraft I., 1968. Physiological and chemical differences in aged seeds. Crop Science, 8: 407-409.

Copeland L. O., 1976. Principles of seed science and technology. Burges Publishing Company, Minneapolis.

Fetch T. G., Schneiter A. A., 1983. Seed vigour evluated in sunflower. Abstracts of the Annual Meeting of the American Society of Agronomy at Washington D. C.

Gó recki R. J., 1982. Viability and vigour of ageing pea seeds with various densities. Acta Soc. Bot. Pol. 51: 481-488.

Górecki R. J., 1986. Studies of vigour of legume seeds [in Polish] Acta Acad. Agric. Techn. Olst. 42, Suplementum A: 1-60.

Górecki R. J., Klasa A., Bałajewicz A., 1985. Proteins in pea seeds after 7 months of storage at 50 and $90 \%$ relative humidity. Acta Soc. Bot. Pol. 54: 367-378.

Górecki R. J., Harman G. E., 1987. Effect of antioxidants on viability and vigour of ageing pea seeds. Seed Sci. Techn. 15: 109-117.

Grzesiuk S., Górecki R. J., 1981. Vigour of seeds as a new criterion of seed quality and methods of its determination (in Polish). Post. Nauk Roln. 6: 39-56.

Grzesiuk S., Kulka K., 1981. Physiology and biochemistry of seeds [in Polish]. PWN, Warszawa.

Grzesiuk S., Tłuczkiewicz J., 1982. Viability and vigour of ageing winter wheat grains. Acta Soc. Bot. Pol. 51: 251-262. 
Hadas A., 1977. A suggested method for testing seed vigour under water stress in simulated arid conditions. Seed Sci. Techn. 5: 519-525.

Halmer P., Bewley J. D., 1984. A physiological perspective on seed vigour testing. Seed Sci. Techn. 12: 561-575.

International Seed Testing Association, 1976. International Rules for Seed Testing 1976. Seed Science and Technology, 4: 1-177.

Justice D. L., Bass L. N., 1978. Principles and practices of seed storage. Agriculture Handbook No. 506, Washington $D$. C.

Marshall A. H., Naylor R. E., 1985. Seed vigour and field establishment in Italian ryegrass (Lolium multiflorum Lam.) Seed Sci. Techn. 13: 781-794.

Michel B. E., Ka ufmann M. R., 1973. The osmotic potential of polyethylene glycol 6000 . Plant Physiol. 51: 914-916.

Mugnisjah W. Q., Nakamura S.. 1986. Methanol and ethanol stress for seed vigour evaluation in soybean. Seed Sci. Techn. 14: 95-103.

Musgrave M. E., Priestley D. A., Leopold C. A., 1980. Methanol stress as a test of seed vigour. Crop Sci. 20: 626-630.

Perry D. A., 1977. A vigour test for seeds of barley (Hordeum vulgare L.) based on measurment of plumule growth. Seed Sci. Techn. 5: 709-719.

Perry D. A., 1981. Handbook of vigour test methods. International Seed Testing Association, Zurich.

Powell A. A., 1986. Cell membranes and seed leachate conductivity in relation to the quality of seed for sowing. J. Seed Techn. 10: 81-100.

Powell A. A., Matthews S. 1977. Deteriorative changes in pea seeds (Pisum sativum L.) stored in humid or dry conditions. J. Exp. Bot. 28: 225-234.

Roberts E. H., 1981. Physiology of ageing and its application to drying and storage. Seed Sci. Techn. 9: 359-372.

Roberts E. H., Ellis R. H., 1982. Physiological, ultrastructural and metabolic aspects of seed viability. [In:] The physiology and biochemistry of seed development, dormancy and germination. A. A. Khan (ed.), pp. 465-485.

Roos E. E., 1980. Physiological, biochemical, and genetic changes in seed quality during storage. Hort Sci. 15, 19-26.

\section{Ocena wigoru nasion kupkówki (Dactylis glomerata L.) o różnym wieku}

\section{Streszczenie}

Badano nasiona dwu odmian kupkówki pospolitej (Dactylis glomerata L.) ze zbiorów w latach 1986, 1985, 1984 i 1983, przechowywanych w magazynie o nie kontrolowanej temperaturze i wilgotności względnej powietrza. Próbki nasion nie różniły się istotnie pod względem żywotności. Znaczne zróżnicowanie stwierdzono w wigorze nasion, który oznaczano na podstawie wschodów polowych, szybkości wzrostu siewek, testu stresu osmotycznego i testu stresu etanolowego. Test konduktometryczny okazal się metodą nieprzydatną do określenia wigoru nasion kupkówki. W pracy przedyskutowano także metodyczne aspekty oznaczania wigoru nasion tego gatunku. 